\title{
Involvement of polymorphisms of the nerve growth factor and its receptor encoding genes in the etiopathogenesis of ischemic stroke
}

\author{
Ani Stepanyan ${ }^{*}$ (D), Roksana Zakharyan ${ }^{1}$, Arsen Simonyan, Gohar Tsakanova ${ }^{1}$ and Arsen Arakelyan ${ }^{1}$
}

\begin{abstract}
Background: Despite the important role of the nerve growth factor in the survival and maintenance of neurons in ischemic stroke, data regarding the relationships between variations in the encoding gene and stroke are lacking. In the present study, we evaluated the association of the functional polymorphisms in NGF (rs6330) and NGFR (rs2072446 and rs734194) genes with ischemic stroke in an Armenian population.

Methods: In total, 370 unrelated individuals of Armenian nationality were enrolled in this study. Genomic DNA samples of patients and healthy controls were genotyped using polymerase chain reaction with sequence-specific primers.

Results: The results obtained indicate that the minor allele of rs6330 ( $\left.P_{\text {corr }}=2.4 \mathrm{E}-10\right)$ and rs2072446 $\left(P_{\text {corr }}=0.02\right)$ are significantly overrepresented in stroke group, while the minor allele of rs734194 ( $\left.P_{\text {corr }}=8.5 \mathrm{E}-10\right)$ was

underrepresented in diseased subjects. Single nucleotide polymorphisms in NGF gene (rs6330) and NGFR gene (rs2072446 and rs734194) are associated with the disease. Furthermore, it was shown that the carriage of the NGF rs6330*T minor allele is associated with increased infarct volume and higher risk of recurrent stroke.

Conclusions: In conclusion, our findings suggest that the NGF rs6330*T and NGFR rs2072446*T minor alleles might be nominated as a risk factor for developing ischemic stroke and NGFR rs $734194^{*} G$ minor allele as a protective against this disease at least in Armenian population.
\end{abstract}

Keywords: Ischemic stroke, Nerve growth factor, Nerve growth factor receptor, NGF, NGFR, Single nucleotide polymorphism

\section{Background}

According to the World Health Organization, 15 million people suffer stroke worldwide each year, six million of them die and five million remain partially or completely disabled. Stroke is the second leading cause of disability and death above the age of 60 years, and the fifth leading cause of death in people aged 15 to 59 years old [1]. Stroke problem is urgent for developing world, because the incidence of this disease is increasing. Thus, according to the last data published by Ministry of Health of

\footnotetext{
* Correspondence: a_stepanyan@mb.sci.am

${ }^{1}$ Institute of Molecular Biology NAS RA, 7 Hasratyan Str, 0014 Yerevan,

Armenia

Full list of author information is available at the end of the article
}

Armenia, in 2015 there were approximately new 768 cases of cerebrovascular disease incidence and 81 lethal cases per 100,000 general population of Armenia [2].

Growing evidence suggests that nerve growth factor (NGF) besides its neurotrophic function has sufficient influence on inflammatory and vascular endothelial cells $[3,4]$. Previous studies demonstrated that altered presence of NGF and its receptor (NGFR) are linked to several important processes such as vascular hypertension [5], atherogenesis [6] and inflammation [7] which are considered to be risk factors for the development of ischemic stroke (IS). Moreover, NGF plays an important role in the processes of neuronal survival, ischemic tolerance of the brain and it is involved in the mechanism by 
which neurons can be protected from cell death. Likewise, it was found that intraventricular NGF ameliorated the development of delayed neuronal death [8]. NGF is a known activator for ERK5 (mitogen-activated protein kinase 5) which is key modulator of neuroprotection [9]. Furthermore, NGF up-regulates the expression of the KLF4 transcription factor that plays important role in initiating an anti-apoptotic and anti-inflammatory response [10]. Thus, recent studies suggest ERK5/KLF4 cascade as a common downstream signaling pathway for NGF-induced neuroprotection against oxidative stress [11]. Hence NGF is involved in several crucial processes related to IS etiopathogenesis and it is a good candidate to influence the susceptibility to IS, which is considered to be a complex polygenic disease [12]. There are number of single nucleotide polymorphisms (SNPs) in genes encoding NGF and NGFR that may alter their function and expression levels [13]. Thus, we have used a candidate polymorphism study approach to identify the possible association of the several functional SNPs (Fig. 1) in the genes encoding NGF (rs6330 and rs4839435) and NGFR (rs11466155, rs2072446 and rs734194) with IS in Armenian population. These polymorphisms were selected based on previous studies implicating them in several neurodegenerative, psychological, neurological and neurovascular diseases [13-15].

\section{Methods}

\section{Subjects}

In total, 170 patients with IS (males/females: 88/82; mean age \pm SD: $55 \pm 9.7$ years) and 200 healthy subjects (males/females: 109/91; mean age \pm SD: $49 \pm 9.2$ years) were enrolled in this study. All subjects were unrelated Caucasians of Armenian ancestry.

Patients were hospitalized in the neurological departments of medical centers of the Ministry of Health of Republic of Armenia (MH RA). Diagnosis of IS was based on clinical history and neurological examination of patients and was confirmed by brain computer tomography $(\mathrm{CT})$ imaging and basal laboratory tests. According to the CT used for the quantitative assessment of the volume of the ischemic area, in $42.5 \%$ of IS patients the volume of infarct area was less than $60 \mathrm{~cm}^{3}$ and in $57.5 \%$ of patients the volume of infarct area was more than $60 \mathrm{~cm}^{3}$. Stroke subtype was classified according to TOAST definitions [16]. Stroke severity was scored using the $\mathrm{Na}$ tional Institutes of Health Stroke Scale [17]. Among IS patients involved in this study 38 had cardioembolic stroke and 132 had atherothrombic stroke. Sixty six patients presented anatomically relevant CT hypodense areas in cortical-subcortical parts of cerebral right hemisphere, 97 in left hemisphere and 7 in brain stem. Among IS patients 112 had hyperlipidemia, 87 had arterial hypertension, 40 had atrial fibrillation and 66 had coronary artery disease. With regard to the lifestyle habits 110 patients were current smokers, and 59 were alcohol consumers. Seventy eight patients had positive family history of IS, including 48 maternal, 27 paternal and 3 biparental inheritance.

Healthy subjects (controls) without family history of IS and myocardial infarction were recruited among the blood donors of the Erebouni Medical Center of the MH RA and Blood Bank of Haematology Center after prof. R.Yeolyan. Healthy controls had no serious medical disorders, including coronary artery disease, atrial fibrillation, arterial
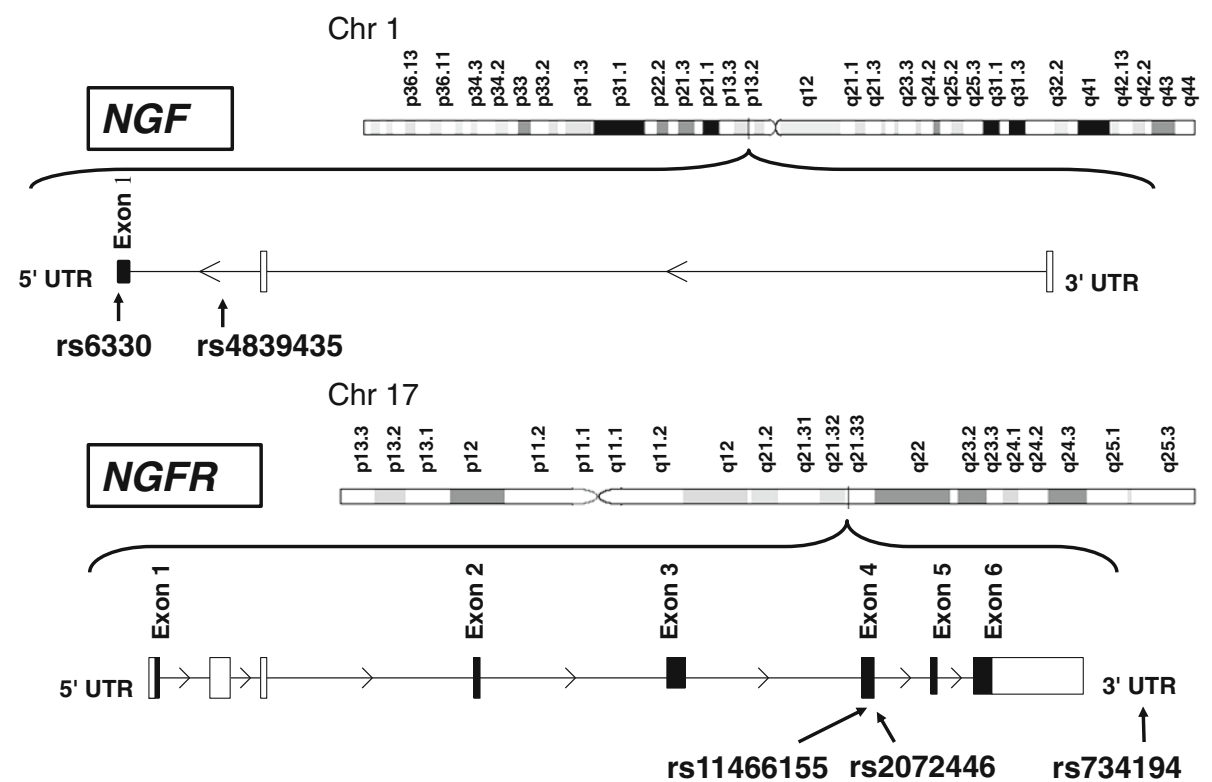

Fig. 1 The localization of the selected 5 SNPs in NGF gene and NGFR gene 
hypertension, and hyperlipidemia, or treatment during the past 12 months. No special studies have been performed to assess the progress of atherosclerotic process in healthy subjects group. Exclusion criteria for all subjects included past or present history of neuropsychiatric metabolic disorders, myocardial infarction, as well as oncological and immune system diseases.

\section{Collection of blood samples and extraction of genomic DNA}

About $5 \mathrm{ml}$ of venous blood was collected from each study subject by venipuncture in EDTA-containing tubes. Blood samples of IS patients were collected on days 1-4 of stroke onset. Genomic DNA was isolated from fresh blood samples according to the standard phenol-chloroform method and stored at $-30{ }^{\circ} \mathrm{C}$ until further use [18].

\section{Selection of the SNPs in NGF and NGFR genes}

According to the National Center of Biotechnology Information (NCBI) databases [http://www.ncbi.nlm.nih.gov/], from 6132 SNPs found in NGF gene and from 2714 SNPs in NGFR gene the 120 and 178 SNPs are nonsynonymous, respectively. From these SNPs we selected those which: 1) have MAFs $>0.05 ; 2$ ) have reported association with several neurological and neurovascular diseases; 3) presumably have influence on structure and/ or function of NGF and NGFR proteins and 4) were linked to altered protein levels in serum $[13,19-26]$.

\section{Genotyping of selected SNPs in NGF and NGFR genes}

All DNA samples were genotyped for selected SNPs using polymerase chain reaction with sequence specific primers (PCR-SSP) using earlier described conditions
$[13,18]$. Detailed characterizations of the NGF rs6330 and rs4839435, as well as NGFR rs11466155, rs2072446 and rs734194 SNPs are shown in Fig. 1 and Table 2. All primers for the PCR-SSP were designed using the reference genomic sequences in the GenBank (http://www.ncbi.nlm.nih.gov). The primer sequences designed for mentioned SNPs and amplicons length are shown in Table 1.

The presence/absence of allele-specific amplicons in PCR products was visualized by electrophoresis in $2 \%$ agarose gel stained with ethidium bromide.

\section{Statistical analysis}

Distribution of genotypes for the mentioned SNPs was checked for correspondence to Hardy-Weinberg equilibrium (HWE) by Pearson $X^{2}$ test. To reveal a potential association of these SNPs with IS, genotype, allele, and phenotype frequencies (carriage rates) in patients and controls were compared. The significance of differences between study groups in multiplicative, dominant and recessive models was determined using a Fisher's exact test. With regard to additive model the differences in genotype distribution of the polymorphisms between case and control subjects were tested by logistic regression. The odds ratio (OR), 95\% confidence interval $(\mathrm{CI})$, and exact $P$ value $\left(P_{\text {nom }}\right)$ were calculated. Nominal $P$ values $\left(P_{\text {nom }}\right)$ were adjusted for multiple testing by Bonferroni correction (factor 5). Corrected $P$ values $\left(P_{\text {corr }}\right)<0.05$ were considered significant [27]. The Mann-Whitney U (quantitative variables) and Fisher's exact test (nominal and ordinal variables) were used to evaluate the possible differences of the clinical characteristics between minor allele carrier and non-carriers IS patients.

Table 1 The primer sequences and amplicons size of the studied SNPS

\begin{tabular}{|c|c|c|c|c|c|}
\hline Gene & Accession & SNP ID & Primer type & Nucleotide sequence of primer $\left(5^{\prime} \rightarrow 3^{\prime}\right)$ & Amplicon size, bp \\
\hline \multirow[t]{6}{*}{ NGF } & NG_007944 & rs6330 & reverse for standard $\mathrm{C}$ allele & CTGAAGTTTAGTCCAGTGGG & 187 \\
\hline & & & reverse for minor $T$ allele & CTGAAGTTTAGTCCAGTGGA & \\
\hline & & & forward constant & CTGCATTTAGTACTCCATGAA & \\
\hline & & rs4839435 & forward for standard $\mathrm{G}$ allele & TGGGTGCCAAAAAGCTTGGC & 188 \\
\hline & & & forward for minor A allele & TGGGTGCCAAAAAGCTTGGT & \\
\hline & & & reverse constant & GCAGCTCCTGCAATTATCCA & \\
\hline \multirow[t]{9}{*}{ NGFR } & AC006487 & rs11466155 & reverse for standard $\mathrm{C}$ allele & AGGCTATGTAGGCCACAAGG & 210 \\
\hline & & & reverse for minor $\mathrm{T}$ allele & AGGCTATGTAGGCCACAAGA & \\
\hline & & & forward constant & CAGAGGGCTCGGACAGCACA & \\
\hline & & rs2072446 & forward for standard C allele & GTCCACACCCCCAGAGGGCTC & 190 \\
\hline & & & forward for minor T allele & GTCCACACCCCCAGAGGGCTT & \\
\hline & & & reverse constant & AGCAGCCAGGATGGAGCAAT & \\
\hline & & rs734194 & forward for standard T allele & GCTGGAGCTGGCGTCTGTCT & 186 \\
\hline & & & forward for minor G allele & GCTGGAGCTGGCGTCTGTCG & \\
\hline & & & reverse constant & CTAGAGCTGGGAGAAATCCC & \\
\hline
\end{tabular}




\section{Results}

The genotyping analysis showed that genotype distribution of the NGF gene rs6330 and rs4839435 and the NGFR gene rs11466155, rs2072446 and rs734194 SNPs in study groups were concordant with HWE $(P>0.05)$ (Table 2). Furthermore, the observed minor allele frequencies (MAFs) of the studied SNPs (Table 2) in Armenian population were compared from those reported in major $(n=2504)$ population of the $1000 \mathrm{Ge}$ nomes Project. The results showed significant difference between MAFs of the NGF gene rs4839435 as well as NGFR gene rs2072446 and rs734194 SNPs in Armenian population compared to 1000 Genomes Project data, whereas there was no difference for other two studied SNPs (NGF gene rs6330 and NGFR gene rs11466155) (Table 2). SNP analysis revealed that rs6330 variation of the NGF gene is associated with IS in the multiplicative model $\left(P_{\text {corr }}=3.6 \mathrm{E}-11\right)$, the dominant model $\left(P_{\text {corr }}=\right.$ $2.4 \mathrm{E}-10)$, the recessive model $\left(P_{\text {corr }}=0.001\right)$, and the additive model $\left(P_{\text {corr }}=0.0005\right)$ (Table 3$)$. Moreover, the frequency and carriage (dominant model) of NGF rs6330*T minor allele were $1.98\left(0.406\right.$ vs. $0.205 ; P_{\text {corr }}=$ $3.6 \mathrm{E}-11)$ and $1.85\left(0.647\right.$ vs. $\left.0.35 ; P_{\text {corr }}=2.4 \mathrm{E}-10\right)$ times respectively increased in IS patients in comparison with healthy controls (Table 3). In IS patients group, MannWhitney $U$ test revealed statistically significant difference of the volumes of ischemic area between NGF gene rs6330* $\mathrm{T}$ minor allele carriers and non-carriers $(\mathrm{CT}+$ TT vs. CC; $188 \pm 234 \mathrm{~cm}^{3}$ vs. $\left.72 \pm 128 \mathrm{~cm}^{3} ; P=0.023\right)$. Furthermore, $27 \%$ of all patients enrolled in study experienced second or third IS; and also there were significantly higher number of recurrent IS events in $\mathrm{T}$ minor allele carriers compared to non-carriers $(\mathrm{CT}+\mathrm{TT}$ vs. CC, $39.3 \%$ vs. $10.5 \%$; $\mathrm{OR}=5.71 ; 95 \% \mathrm{CI}: 2.68-12.2 ; P=$ 1.0E-6).

According to the data obtained for the genotyping of the NGFR gene rs2072446 SNP, the frequency and carriage (multiplicative and dominant models) of $\mathrm{T}$ minor allele were $1.29\left(0.378\right.$ vs. $\left.0.293 ; P_{\text {corr }}=0.04\right)$ and $1.26(0.6$ vs. $\left.0.475 ; P_{\text {corr }}=0.02\right)$ times respectively increased in IS patients compared to controls. Further, there were statistically significant difference of the frequencies of the rs2072446 polymorphism CC, CT and TT genotypes (additive model) between patients and controls groups $\left(P_{\text {corr }}=0.0005\right)$.

A strong negative association was detected between IS and NGFR gene rs734194 genetic variation in the all studied models (multiplicative $P_{c o r r}=1.1 \mathrm{E}-11$; dominant $P_{\text {corr }}=8.5 \mathrm{E}-10$; recessive $P_{\text {corr }}=4.8 \mathrm{E}-4$; additive $P_{\text {corr }}=$ $0.0005)$ (Table 3). Particularly, NGFR rs734194*G minor allele frequency and carriage were 2.73 (0.1 vs. 0.273 ; $\left.P_{\text {corr }}=1.1 \mathrm{E}-11\right)$ and $2.42\left(0.188\right.$ vs. $\left.0.455 ; P_{\text {corr }}=8.5 \mathrm{E}-10\right)$ times respectively decreased in IS patients in comparison with controls.

Finally, no association with IS were observed for rs4839435 SNP of the NGF gene and the rs11466155 SNP of the NGFR genes (Table 3).

According to LD analysis results (Table 4) NGF gene rs6330 and rs4839435, as well as NGFR gene rs11466155, rs2072446 and rs734194 SNPs are not in strong LD among all studied groups. Furthermore, LD between selected SNPs in NGFR gene in Armenian population differs from LD in population samples from the HapMap Project [28]. As for obtained linkage between NGF gene rs6330 and rs4839435 SNPs in Armenian population it is almost the same as in HapMap (Table 4).

In order to evaluate an interaction between the significant alleles at the two loci (NGF rs6330/NGFR rs2072446) we compared the relative risk of IS in patients carrying one of the risk alleles with those who have two risk alleles at both loci. Increased relative risk for IS was observed in double risk allele carrier patients compared to carriers of either NGF rs6330*T or NGFR rs2072446*T alleles (Table 5).

Table 2 HWE and MAFs of the selected SNPs in the studied groups and in major population

\begin{tabular}{|c|c|c|c|c|c|c|}
\hline \multirow[t]{2}{*}{ Gene SNP ID } & \multirow{2}{*}{$\begin{array}{l}\text { Minor } \\
\text { allele }\end{array}$} & \multicolumn{3}{|c|}{ MAF (frequency/number) } & \multicolumn{2}{|l|}{ HWE $(P)$} \\
\hline & & IS patients & Controls & 1000 Genomes & IS patients & Controls \\
\hline \multirow[t]{2}{*}{ NGF rs6330 } & $T$ & $0.406 / 138$ & $0.205 / 82$ & $0.248 / 1239$ & 0.95 & 0.12 \\
\hline & & & $P=0.06$ & & & \\
\hline \multirow[t]{2}{*}{ NGF rs4839435 } & A & $0.344 / 117$ & $0.333 / 133$ & $0.176 / 880$ & 0.98 & 0.165 \\
\hline & & & $P<0.0001$ & & & \\
\hline \multirow[t]{2}{*}{ NGFR rs 11466155} & T & $0.282 / 96$ & $0.263 / 102$ & $0.229 / 1151$ & 0.5 & 0.6 \\
\hline & & & $P=0.25$ & & & \\
\hline \multirow[t]{2}{*}{ NGFR rs2072446 } & $\mathrm{T}$ & $0.378 / 125$ & $0.293 / 117$ & $0.053 / 264$ & 0.99 & 0.094 \\
\hline & & & $P<0.0001$ & & & \\
\hline \multirow[t]{2}{*}{ NGFR rs 734194} & G & $0.1 / 34$ & $0.273 / 109$ & $0.106 / 533$ & 0.72 & 0.26 \\
\hline & & & $P<0.0001$ & & & \\
\hline
\end{tabular}


Table 3 Association of the NGF and NGFR genes SNPs with IS risk under different models

\begin{tabular}{|c|c|c|c|c|c|c|c|}
\hline \multirow[t]{2}{*}{ Gene SNP (M/m) } & \multirow[t]{2}{*}{ Groups } & \multicolumn{3}{|c|}{ Genotypes (number/frequency) } & \multirow[t]{2}{*}{ Model } & \multirow[t]{2}{*}{ OR $(95 \% \mathrm{Cl})$} & \multirow[t]{2}{*}{$P_{\text {nom }}$} \\
\hline & & MM & $\mathrm{Mm}$ & $\mathrm{mm}$ & & & \\
\hline \multirow[t]{4}{*}{ NGF rs6330 (C/T) } & IS patients & $60(0.35)$ & $82(0.48)$ & $28(0.175)$ & multiplicative & $2.65(1.996-3.5)$ & $7.3 \mathrm{E}-12$ \\
\hline & & & & & dominant & $3.39(2.35-4.89)$ & $4.8 \mathrm{E}-11$ \\
\hline & Controls & $130(0.65)$ & $58(0.29)$ & $12(0.06)$ & recessive & $3.07(1.65-5.72)$ & 0.0002 \\
\hline & & & & & additive & $3.409(2.3-5.054)$ & $<0.0001$ \\
\hline \multirow[t]{4}{*}{ NGF rs4839435 (G/A) } & IS patients & $73(0.43)$ & $77(0.45)$ & $20(0.12)$ & multiplicative & $1.05(0.81-1.37)$ & 0.45 \\
\hline & & & & & dominant & $0.98(0.69-1.4)$ & 1 \\
\hline & Controls & $85(0.425)$ & $97(0.485)$ & $18(0.09)$ & recessive & $1.35(0.76-2.39)$ & 0.3 \\
\hline & & & & & additive & $0.851(0.58-1.24)$ & 0.4 \\
\hline \multirow[t]{4}{*}{ NGFR rs11466155 (C/T) } & IS patients & $86(0.505)$ & $72(0.424)$ & $12(0.071)$ & multiplicative & $1.11(0.84-1.46)$ & 0.48 \\
\hline & & & & & dominant & $1.19(0.84-1.69)$ & 0.32 \\
\hline & Controls & $110(0.55)$ & $75(0.375)$ & $15(0.075)$ & recessive & $1.06(0.54-2.07)$ & 0.86 \\
\hline & & & & & additive & $1.791(1.15-2.79)$ & 0.011 \\
\hline \multirow[t]{4}{*}{ NGFR rs2072446 (C/T) } & IS patients & $68(0.4)$ & $79(0.465)$ & $23(0.135)$ & multiplicative & $1.43(1.09-1.86)$ & 0.008 \\
\hline & & & & & dominant & $1.68(1.18-2.39)$ & 0.004 \\
\hline & Controls & $105(0.525)$ & $73(0.365)$ & $22(0.11)$ & recessive & $1.3(0.76-2.23)$ & 0.3 \\
\hline & & & & & additive & $2.327(1.56-3.48)$ & $<0.0001$ \\
\hline \multirow[t]{4}{*}{ NGFR rs734194 (T/G) } & IS patients & $138(0.81)$ & $30(0.18)$ & $2(0.01)$ & multiplicative & $3.36(2.36-4.78)$ & $2.3 \mathrm{E}-12$ \\
\hline & & & & & dominant & $3.62(2.42-5.42)$ & 1.7E-10 \\
\hline & Controls & $109(0.545)$ & $73(0.365)$ & $18(0.09)$ & recessive & 7.95 (2.35-26.89) & $9.7 E-5$ \\
\hline & & & & & additive & $0.182(0.11-0.32)$ & $<0.0001$ \\
\hline
\end{tabular}

"M/m" indicates major/minor alleles; multiplicative model indicates " $\mathrm{M}$ vs. $\mathrm{m}$ "; dominant model indicates "Mm + $\mathrm{mm}$ vs. $\mathrm{MM}$ "; recessive model indicates "MM + Mm vs. $\mathrm{mm}^{\prime}$; additive model indicates "MM vs. Mm vs. $\mathrm{mm}^{\prime}$

\section{Discussion}

In the current study, we observed positive association of the NGF gene rs6330 and NGFR gene rs2072446 SNPs with IS. In contrast, rs734194 genetic variant of the NGFR gene showed negative association with IS susceptibility. We have also observed that the carriage of the T minor allele of NGF gene rs6330 polymorphism is associated with increased infarct volume and higher risk of recurrent IS.

Recent GWAS reported number of loci which are associated with IS risk [29-31]. Despite the populations included in these studies were almost the same, still differences in reported results were present. Thus the study by Ikram et al. [31] identified two intergenic SNPs within $11 \mathrm{~kb}$ of the gene NINJ2 associated with IS. Two recent GWAS studies $[29,30]$ did not replicate this finding, however, partially confirmed several loci reported from other studies $[32,33]$ as well as identified new ones. Despite the fact that latter studies were performed by same consortium, only four loci were overlapping. The general disparity of the results might be partly explained by different quality control filters before imputation as well as methods for assessing population structure in GWAS or due to genetic differences between populations included in these studies. For example, an association of the PRKCH locus with stroke identified in a GWAS in Japanese participants was not found in European populations [30].

Genomic loci that are associated with increased stroke susceptibility and were reported by recent GWAS in European, non-Hispanic black and Hispanic ancestry samples do not include NGF and NGFR genes [29, 30]. Inconsistency of our data with the published results might be explained due to a long period of isolation of Armenian population since the Bronze Age and subsequently a unique profile of rare disease alleles [34]. Furthermore, recent studies reported very restricted genetic affinities of Armenians with European populations $[35,36]$. From the other side the genetic structure of Armenian population is still largely unknown, which forces as to employ candidate gene approach to study NGF and NGFR, since their involvement in neuroprotection after IS and several pathogenic processes contributing to the development of IS is well documented [5-9].

NGF rs6330 and NGFR rs2072446 functional SNPs lead to non-synonymous amino acid substitutions and are possibly involved in the gene expression and protein secretion [13, 19]. The first one is described as a $\mathrm{C} 104 \rightarrow \mathrm{T}$ exchange in exon 1 of the NGF gene and 
Table 4 LD values (the absolute $D^{\prime \prime}$ and $r^{2}$ ) IS patients (b), and $r^{2}$ values calculated from the data obtained for Armenian population involved in this study and for the results available on HapMap (c)

\begin{tabular}{|c|c|c|c|c|c|}
\hline \multicolumn{6}{|l|}{ (a) } \\
\hline$r^{2} /\left|D^{\prime}\right|$ & NGF rs6330 & NGF rs4839435 & NGFR rs 11466155 & NGFR rs 2072446 & NGFR rs734194 \\
\hline NGF rs6330 & - & 0.01867 & - & - & - \\
\hline NGF rs4839435 & 0.18280 & - & - & - & - \\
\hline NGFR rs11466155 & - & - & - & 0.01859 & 0.10206 \\
\hline NGFR rs2072446 & - & - & 0.14499 & - & 0.01801 \\
\hline NGFR rs734194 & - & - & 0.34901 & 0.13786 & - \\
\hline \multicolumn{6}{|l|}{ (b) } \\
\hline$r^{2} /\left|D^{\prime}\right|$ & NGF rs6330 & NGF rs4839435 & NGFR rs 11466155 & NGFR rs2072446 & NGFR rs734194 \\
\hline NGF rs6330 & - & 0.06598 & - & - & - \\
\hline NGF rs4839435 & 0.28271 & - & - & - & - \\
\hline NGFR rs11466155 & - & - & - & 0.12024 & 0.07141 \\
\hline NGFR rs2072446 & - & - & 0.41654 & - & 0.08063 \\
\hline NGFR rs734194 & - & - & 0.49926 & 0.63728 & - \\
\hline \multicolumn{6}{|l|}{ (c) } \\
\hline Armenians/HapMap & NGF rs6330 & NGF rs4839435 & NGFR rs 11466155 & NGFR rs2072446 & NGFR rs734194 \\
\hline NGF rs6330 & - & 0.01867 & - & - & - \\
\hline NGF rs4839435 & 0.012 & - & - & - & - \\
\hline NGFR rs11466155 & - & - & - & 0.01859 & 0.10206 \\
\hline NGFR rs2072446 & - & - & 0.001 & - & 0.01801 \\
\hline NGFR rs734194 & - & - & 0.002 & 0.609 & - \\
\hline
\end{tabular}

For each pair of SNPs $r^{2}$ and $\left|D^{\prime \prime}\right|$ values are shown above and below the dioganal, respectively

leads to amino acid substitution of alanine to valine at position 35 (Ala35Val). Some authors suppose that the increase in amino acid size at this position could modify the tertiary structure of NGF, leading to altered interaction and signaling via the NGFR [20]. Therefore, $\mathrm{T}$ minor allele could be a risk factor for IS through its possible involvement in increased cell death and consequently, decreased neuronal survival after ischemia. This is consistent with our findings on association of rs6330*T minor allele with increased lesion volume after IS. With regard to NGFR rs2072446 polymorphism, the $\mathrm{C} 739 \rightarrow \mathrm{T}$ nucleotide transition in exon 4 leads to serine to leucine substitution at the amino acid position 205 (Ser205Leu) and the change of polar (hydrophilic) amino acid to nonpolar (hydrophobic) subsequently, causes alteration of the NGFR protein structure and function [21]. In addition, rs734194 is located on 3' UTR and thereby it could be engaged in regulating the mRNA stability and translational efficiency. Hence, it is possible that this SNP alters the expression of NGFR or the binding of NGF, which can decrease neuronal apoptosis rate [22]. All together, these mechanisms may partially explain the involvement of the NGF rs6330 and the NGFR rs2072446 in the higher risk of IS, and the protective role of NGFR rs734194 against this disease observed in our study.

Recent studies reported that rs6330, rs2072446 and rs734194 genetic variants are associated with number of neurovascular and psychiatric diseases, which might predispose to stroke and increase its likelihood [23, 24]. Particularly, it was shown that NGF rs6330*T minor allele is positively associated with the risk of migraine, schizophrenia and Alzheimer's disease [13, 14, 25]. As for NGFR rs2072446, it was observed as being associated with depression and schizophrenia $[13,15]$. Furthermore, inherited rs734194 polymorphism of NGFR gene was associated with the decreased risk of obsessive-compulsive

Table 5 Relative risk of IS among carriers of NGF rs6330*T, NGFR rs2072446*T and TT (rs6330/rs2072446) alleles

\begin{tabular}{llll}
\hline & NGF rs6330*T & NGFR rs2072446*T & T(rs6330/rs2072446) \\
\hline Relative risk & 1.85 & 1.26 & 2.16 \\
$95 \% \mathrm{Cl}$ & $1.48-2.3$ & $1.05-1.53$ & $1.46-3.17$ \\
Significance level & $P<0.0001$ & $P=0.001$ & $P=0.0001$ \\
\hline
\end{tabular}


disease, schizophrenia and Alzheimer's disease [13, 22, 26].

According to the data of Cerebrovascular Disease Knowledge Portal most recent GWAS have discovered associations between the studied sequence variants in $N G F$ and NGFR gene and cerebrovascular disease or related traits. Thus, NGFR gene rs2072446 polymorphism was associated with IS of TOAST undetermined etiology $(p=0.037)$, large artery atherosclerosis $(p=0.03)$, height $(p=0.01)$ and waist-hip ratio $(p=0.013)[29,37-40]$. Regarding NGFR gene rs734194 SNP, its minor allele showed association with TOAST small artery occlusion $(p=0.02)$, Type 2 diabetes $(p=0.019)$, height $(p=0.019)$, serum cystatin $C(p=0.016)[39,41-44]$. However, this is the first study to evaluate the association of the genetic variations of the NGF and the NGFR genes with IS, infarction size and recurrence of the disease in Armenian population. Thus, our findings indicate that mentioned above SNPs could play a potential role in the etiopathogenesis of IS. We suggest that further studies are required to clarify the functional consequences of the mentioned SNPs as well as NGF and NGFR genes in the etiology and the molecular pathomechanisms of IS. Our results are preliminary and they need to be confirmed in studies with larger sample size and in different ethnic groups.

\section{Conclusions}

Our findings suggest that the NGF rs6330*T and NGFR rs2072446*T minor alleles might be nominated as a risk factor for developing IS and NGFR rs734194*G minor allele as a protective against this disease in Armenian population.

\section{Abbreviations \\ Cl: Confidence interval; CT: Computer tomography; HWE: Hardy-Weinberg equilibrium; IS: Ischemic stroke; MAF: Minor allele frequency; NGF: Nerve growth factor; NGFR: Nerve growth factor receptor; OR: Odds ratio; PCR- SSP: Polymerase chain reaction with sequence specific primers; SNP: Single nucleotide polymorphism}

\section{Acknowledgments}

We express our sincere thanks to the administration and medical staff of the neurological departments of medical centers of the Ministry of Health of RA, as well as to junior researchers of the Laboratory of Human Genomics and Immunomics of the Institute of Molecular Biology NAS RA, Ani Melqonyan and Karine Tadevosyan.

\section{Funding}

This study was supported by the funding project of the National Academy of Sciences of the Republic of Armenia (E-18) and the State Committee of Science MES RA in the frame of 16YR-1F011 research project.

\section{Availability of data and materials}

The sequences of all primers for the PCR-SSP were designed using the genomic sequences in the GenBank (http://www.ncbi.nlm.nih.gov) with the accession codes NG_007944 and AC006487.

The MAFs data of the investigated SNPs in major population that support the findings of this study were reported by 1000 Genomes Project and are available in The National Center for Biotechnology Information (NCBI) [https://www.ncbi.nlm.nih.gov/] with the identifiers [rs4839435, rs2072446, rs734194, rs6330, rs11466155].

The authors declare that all other data supporting the findings of this study are available within the article.

\section{Authors' contributions}

All authors contributed extensively to the work presented in this paper. AS performed the experiments, analyzed the data and wrote the manuscript, RZ designed the primers and jointly performed the experiments, ArS participated in the collection of blood samples helped with the analysis of the clinical histories of the patients, GT jointly wrote the manuscript and helped to evaluate and edit the manuscript, AA designed and supervised the experiments, as well as helped with the data analysis and interpretation. All authors revised and approved the final version of the manuscript.

Ethics approval and consent to participate

All subjects or their legal representatives gave their informed consent to participate in the study, which was approved by the Ethical Committee of the Institute of Molecular Biology of the National Academy of Sciences RA (IRB00004079).

\section{Consent for publication}

Not applicable.

\section{Competing interests}

The authors declare that they have no competing interests.

\section{Publisher's Note}

Springer Nature remains neutral with regard to jurisdictional claims in published maps and institutional affiliations.

\section{Author details \\ ${ }^{1}$ Institute of Molecular Biology NAS RA, 7 Hasratyan Str, 0014 Yerevan, Armenia. ${ }^{2}$ Hospital and Polyclinic №2 CJSC, 54 Aram Str, 0002 Yerevan,} Armenia.

Received: 9 March 2017 Accepted: 23 February 2018

Published online: 02 March 2018

\section{References}

1. Johnson W, Onuma O, Owolabi M, Sachdev S. Stroke: a global response is needed. Bull World Health Organ. 2016;94(9):634-634A.

2. Khachatryan S, Andreasyan D, Bazarchyan A, Simonyan S, Muradyan G, Torosyan A, Chamanyan A, Matevosyan M, Kostandyan M, Simonyan A, Torgomyan A, Health and Health care yearbook, RA 2016. National institute of health, named after S. Avdalbekyan, MoH, RA; 2016. p. 93-95.

3. Bracci-Laudiero L, De Stefano ME. NGF in early embryogenesis, differentiation, and pathology in the nervous and immune systems. Curr Top Behav Neurosci. 2016;29:125-52.

4. Aloe L, Rocco ML, Balzamino BO, Micera A. Nerve growth factor: role in growth, differentiation and controlling cancer cell development. J Exp Clin Cancer Res. 2016;35(1):116.

5. Sherer TB, Neff PS, Hankins GR, Tuttle JB. Mechanisms of increased NGF production in vascular smooth muscle of the spontaneously hypertensive rat. Exp Cell Res. 1998;241(1):186-93.

6. Chaldakov GN, Stankulov IS, Fiore M, Ghenev PI, Aloe L. Nerve growth factor levels and mast cell distribution in human coronary atherosclerosis. Atherosclerosis. 2001:159(1):57-66.

7. Villoslada P, Hauser SL, Bartke I, Unger J, Heald N, Rosenberg D, Cheung SW, Mobley WC, Fisher S, Genain CP. Human nerve growth factor protects common marmosets against autoimmune encephalomyelitis by switching the balance of T helper cell type 1 and 2 cytokines within the central nervous system. J Exp Med. 2000;191(10):1799-806.

8. Shigeno T, Mima T, Takakura K, Graham DI, Kato G, Hashimoto Y, Furukawa S. Amelioration of delayed neuronal death in the hippocampus by nerve growth factor. J Neurosci. 1991;11(9):2914-9.

9. Wang RM, Yang F, Zhang YX. Preconditioning-induced activation of ERK5 is dependent on moderate Ca2+ influx via NMDA receptors and contributes to ischemic tolerance in the hippocampal CA1 region of rats. Life Sci. 2006;79(19):1839-46. 
10. Ohnesorge N, Viemann D, Schmidt N, Czymai T, Spiering D, Schmolke M, Ludwig S, Roth J, Goebeler M, Schmidt M. Erk5 activation elicits a vasoprotective endothelial phenotype via induction of Kruppel-like factor 4 (KLF4). J Biol Chem. 2010;285(34):26199-210.

11. Su C, Sun F, Cunningham RL, Rybalchenko N, Singh M. ERK5/KLF4 signaling as a common mediator of the neuroprotective effects of both nerve growth factor and hydrogen peroxide preconditioning. Age (Dordr) 2014;36(4):9685

12. Titov BV, Matveeva NA, Martynov MY, Favorova OO. Ischemic stroke as a complex polygenic disease. Mol Biol. 2015;49(2):224-48.

13. Zakharyan R, Atshemyan S, Gevorgyan A, Boyajyan A. Nerve growth factor and its receptor in schizophrenia. BBA Clin. 2014;1:24-9.

14. Coskun S, Varol S, Ozdemir HH, Agacayak E, Aydın B, Kapan O, Camkurt MA, Tunc S, Cevik MU. Association of brain-derived neurotrophic factor and nerve growth factor gene polymorphisms with susceptibility to migraine. Neuropsychiatr DiTreat. 2016;12:1779-85.

15. Colle R, Deflesselle E, Martin S, David DJ, Hardy P, Taranu A, Falissard B, Verstuyft C, Corruble E. BDNF/TRKB/P75NTR polymorphisms and their consequences on antidepressant efficacy in depressed patients. Pharmacogenomics. 2015;16(9):997-1013.

16. Adams HP Jr, Bendixen BH, Kappelle LJ, Biller J, Love BB, Gordon DL, Marsh EE 3rd. Classification of subtype of acute ischemic stroke. Definitions for use in a multicenter clinical trial. TOAST. Trial of org 10172 in acute stroke treatment. Stroke. 1993;24(1):35-41.

17. Muir KW, Weir CJ, Murray GD, Povey C, Lees KR. Comparison of neurological scales and scoring systems for acute stroke prognosis. Stroke. 1996:27(10):1817-20.

18. Sambrook J, Russell DW. Molecular Cloning: A Laboratory Manual, 4th edition. New York: Cold Spring Harbor Laboratory Press; 2001. p. 455-541. https://www.cshlpress.com/pdf/sample/2013/MC4/MC4FM.pdf.

19. Szczepankiewicz A, Rachel M, Sobkowiak P, Kycler Z, Wojsyk-Banaszak I, Schöneich N, Szczawińska-Popłonyk A, Bręborowicz A. Neurotrophin serum concentrations and polymorphisms of neurotrophins and their receptors in children with asthma. Respir Med. 2013;107(1):30-6.

20. Akkad DA, Kruse N, Arning L, Gold R, Epplen JT. Genomic NGFB variation and multiple sclerosis in a case control study. BMC Med Genet. 2008;9:107. https://doi.org/10.1186/1471-2350-9-107.

21. Chang CC, Fang WH, Chang HA, Huang SY. Functional Ser205Leu polymorphism of the nerve growth factor receptor (NGFR) gene is associated with vagal autonomic dysregulation in humans. Sci Rep. 2015:5:13136. https://doi.org/10.1038/srep13136.

22. Cheng HC, Sun Y, Lai LC, Chen SY, Lee WC, Chen JH, Chen TF, Chen HH, Wen LL, Yip PK, Chu YM, Chen WJ, Chen YC. Genetic polymorphisms of nerve growth factor receptor (NGFR) and the risk of Alzheimer's disease. J Negat Results Biomed. 2012;11:5.

23. Chiu YC, Bai YM, Su TP, Chen TJ, Chen MH. Ischemic stroke in young adults and preexisting psychiatric disorders: a Nationwide case-control study. Medicine (Baltimore). 2015;94(38):e1520.

24. Honig LS, Tang MX, Albert S, Costa R, Luchsinger J, Manly J, Stern Y, Mayeux R. Stroke and the risk of Alzheimer disease. Arch Neurol. 2003;60(12):1707-12.

25. Di Maria E, Giorgio E, Uliana V, Bonvicini C, Faravelli F, Cammarata S, Novello MC, Galimberti D, Scarpini E, Zanetti O, Gennarelli M, Tabaton M. Possible influence of a non-synonymous polymorphism located in the NGF precursor on susceptibility to late-onset Alzheimer's disease and mild cognitive impairment. J Alzheimers Dis. 2012;29(3):699-705.

26. Gassó P, Ortiz AE, Mas S, Morer A, Calvo A, Bargalló N, Lafuente A, Lázaro L. Association between genetic variants related to glutamatergic, dopaminergic and neurodevelopment pathways and white matter microstructure in child and adolescent patients with obsessive-compulsive disorder. J Affect Disord. 2015;186:284-92.

27. Aickin M, Gensler H. Adjusting for multiple testing when reporting research results: the Bonferroni vs holm methods. Am J Public Health. 1996;86(5):726-8.

28. Johnson AD, Handsaker RE, Pulit SL, Nizzari MM, O'Donnell CJ, de Bakker PI. SNAP: a web-based tool for identification and annotation of proxy SNPS using HapMap. Bioinformatics. 2008;24(24):2938-9.

29. NINDS Stroke Genetics Network (SiGN); International Stroke Genetics Consortium (ISGC). Loci associated with ischaemic stroke and its subtypes (SiGN): a genome-wide association study. Lancet Neurol. 2016; 15(2):174-84
30. Neurology Working Group of the Cohorts for Heart and Aging Research in Genomic Epidemiology (CHARGE) consortium, the stroke genetics network (SiGN), and the international stroke genetics consortium (ISGC). Identification of additional risk loci for stroke and small vessel disease: a meta-analysis of genome-wide association studies. Lancet Neurol. 2016; 15(7):695-707.

31. Ikram MA, Seshadri S, Bis JC, Fornage M, DeStefano AL, Aulchenko YS, Debette S, Lumley T, Folsom AR, van den Herik EG, Bos MJ, Beiser A, Cushman M, Launer L, Shahar E, Struchalin M, Du Y, Glazer NL, Rosamond WD, Rivadeneira F, Kelly-Hayes M, Lopez OL, Coresh J, Hofman A, DeCarli C, Heckbert SR, Koudstaal PJ, Yang Q, Smith NL, Kase CS, Rice K, Haritunians T, Roks G, de Kort PL, Taylor KD, de Lau LM, Oostra BA, Uitterlinden AG, Rotter II, Boerwinkle E, Psaty BM, Mosley TH, van Duijn CM, Breteler MM, Longstreth WT Jr, Wolf PA. Genomewide association studies of stroke. N Engl J Med 2009;360(17):1718-1728.

32. Holliday EG, Maguire JM, Evans TJ, Koblar SA, Jannes J, Sturm JW, Hankey GJ, Baker R, Golledge J, Parsons MW, Malik R, McEvoy M, Biros E, Lewis MD, Lincz LF, Peel R, Oldmeadow C, Smith W, Moscato P, Barlera S, Bevan S, Bis JC, Boerwinkle E, Boncoraglio GB, Brott TG, Brown RD Jr, Cheng YC, Cole JW, Cotlarciuc I, Devan WJ, Fornage M, Furie KL, Grétarsdóttir S, Gschwendtner A, Ikram MA, Longstreth WT Jr, Meschia JF, Mitchell BD, Mosley TH, Nalls MA, Parati EA, Psaty BM, Sharma P, Stefansson K, Thorleifsson G, Thorsteinsdottir U, Traylor M, Verhaaren BF, Wiggins KL, Worrall BB, Sudlow C, Rothwell PM, Farrall M, Dichgans M, Rosand J, Markus HS, Scott RJ, Levi C, Attia J, Australian Stroke Genetics Collaborative. International Stroke Genetics Consortium; Wellcome Trust Case Control Consortium 2 Common variants at 6p211 are associated with large artery atherosclerotic stroke. Nat Genet. 2012:44(10):1147-51.

33. Traylor M, Farrall M, Holliday EG, Sudlow C, Hopewell JC, Cheng YC, Fornage M, Ikram MA, Malik R, Bevan S, Thorsteinsdottir U, Nalls MA, Longstreth W, Wiggins KL, Yadav S, Parati EA, Destefano AL, Worrall BB, Kittner SJ, Khan MS, Reiner AP, Helgadottir A, Achterberg S, Fernandez-Cadenas I, Abboud S, Schmidt R, Walters M, Chen WM, Ringelstein EB, O'Donnell M, Ho WK, Pera J, Lemmens R, Norrving B, Higgins P, Benn M, Sale M, Kuhlenbäumer G, Doney AS, Vicente AM, Delavaran H, Algra A, Davies G, Oliveira SA, Palmer CN, Deary I, Schmidt H, Pandolfo M, Montaner J, Carty C, de Bakker PI, Kostulas K, Ferro JM, van Zuydam NR, Valdimarsson E, Nordestgaard BG, Lindgren A, Thijs V, Slowik A, Saleheen D, Paré G, Berger K, Thorleifsson G, Australian stroke genetics collaborative, Wellcome Trust case control consortium 2 (WTCCC2), Hofman A, Mosley TH, Mitchell BD, Furie K, Clarke R, Levi C, Seshadri S, Gschwendtner A, Boncoraglio GB, Sharma P, Bis JC, Gretarsdottir S, Psaty BM, Rothwell PM, Rosand J, Meschia JF, Stefansson K, Dichgans M, Markus HS. International stroke genetics consortium. Genetic risk factors for ischaemic stroke and its subtypes (the METASTROKE collaboration): a meta-analysis of genome-wide association studies. Lancet Neurol. 2012;11(11):951-62.

34. Haber M, Mezzavilla M, Xue Y, Comas D, Gasparini P, Zalloua P, Tyler-Smith C. Genetic evidence for an origin of the Armenians from bronze age mixing of multiple populations. Eur J Hum Genet. 2016;24(6):931-6.

35. Herrera KJ, Lowery RK, Hadden L, Calderon S, Chiou C, Yepiskoposyan L, Regueiro M, Underhill PA, Herrera RJ. Neolithic patrilineal signals indicate that the Armenian plateau was repopulated by agriculturalists. Eur J Hum Genet. 2012;20(3):313-20.

36. Margaryan A, Derenko M, Hovhannisyan H, Malyarchuk B, Heller R, Khachatryan Z, Avetisyan P, Badalyan R, Bobokhyan A, Melikyan V, Sargsyan G, Piliposyan A, Simonyan H, Mkrtchyan R, Denisova G, Yepiskoposyan L, Willerslev E, Allentoft ME. Eight millennia of matrilineal genetic continuity in the south Caucasus. Curr Biol. 2017;27(13):2023-8.

37. Cerebrovascular Disease Knowledge Portal, NINDS grant \#1R24NS092983. 2018.02.13; http://cerebrovascularportal.org/variantInfo/variantInfo/ rs2072446\#.

38. Debette S, Kamatani Y, Metso TM, Kloss M, Chauhan G, Engelter ST, Pezzin A, Thijs V, Markus HS, Dichgans M, Wolf C, Dittrich R, Touzé E, Southerland AM, Samson Y, Abboud S, Béjot Y, Caso V, Bersano A, Gschwendtner A, Sessa M, Cole J, Lamy C, Medeiros E, Beretta S, Bonati LH, Grau AJ, Michel P, Majersik JJ, Sharma P, Kalashnikova L, Nazarova M, Dobrynina L, Bartels E, Guillon B, van den Herik EG, Fernandez-Cadenas I, Jood K, Nalls MA, De Leeuw FE, Jern C, Cheng YC, Werner I, Metso AJ, Lichy C, Lyrer PA, Brandt T, Boncoraglio GB, Wichmann HE, Gieger C, Johnson AD, Böttcher T, Castellano M, Arveiler D, Ikram MA, Breteler MM, Padovani A, Meschia JF, Kuhlenbäumer G, Rolfs A, Worrall BB. Common variation in PHACTR1 is 
associated with susceptibility to cervical artery dissection. Nat Genet. 2015; 47(1):78-83. International stroke genetics consortium, Ringelstein EB, Zelenika D, Tatlisumak T, Lathrop M, Leys D, Amouyel P, Dallongeville J; CADISP group

39. Yang J, Loos RJ, Powell JE, Medland SE, Speliotes EK, Chasman DI, Rose LM, Thorleifsson G, Steinthorsdottir V, Mägi R, Waite L, Smith AV, YergesArmstrong LM, Monda KL, Hadley D, Mahajan A, Li G, Kapur K, Vitart V, Huffman JE, Wang SR, Palmer C, Esko T, Fischer K, Zhao JH, Demirkan A, Isaacs A, Feitosa MF, Luan J, Heard-Costa NL, White C, Jackson AU, Preuss M, Ziegler A, Eriksson J, Kutalik Z, Frau F, Nolte IM, Van Vliet-Ostaptchouk JV, Hottenga JJ, Jacobs KB, Verweij N, Goel A, Medina-Gomez C, Estrada K, Bragg-Gresham JL, Sanna S, Sidore C, Tyrer J, Teumer A, Prokopenko I, Mangino M, Lindgren CM, Assimes TL, Shuldiner AR, Hui J, Beilby JP, McArdle WL, Hall P, Haritunians T, Zgaga L, Kolcic I, Polasek O, Zemunik T, Oostra BA, Junttila MJ, Grönberg H, Schreiber S, Peters A, Hicks AA, Stephens J, Foad NS, Laitinen J, Pouta A, Kaakinen M, Willemsen G, Vink JM, Wild SH, Navis G, Asselbergs FW, Homuth G, John U, Iribarren C, Harris T, Launer L, Gudnason V, O'Connell JR, Boerwinkle E, Cadby G, Palmer LJ James AL, Musk AW, Ingelsson E, Psaty BM, Beckmann JS, Waeber G, Vollenweider P, Hayward C, Wright AF, Rudan I, Groop LC, Metspalu A Khaw KT, van Duijn CM, Borecki IB, Province MA, Wareham NJ, Tardif JC, Huikuri HV, Cupples LA, Atwood LD, Fox CS, Boehnke M, Collins FS, Mohlke KL, Erdmann J, Schunkert H, Hengstenberg C, Stark K, Lorentzon M, Ohlsson C, Cusi D, Staessen JA, Van der Klauw MM, Pramstaller PP, Kathiresan S, Jolley JD, Ripatti S, Jarvelin MR, de Geus EJ, Boomsma DI, Penninx B, Wilson JF, Campbell H, Chanock SJ, van der Harst P, Hamsten A, Watkins H, Hofman A, Witteman JC, Zillikens MC, Uitterlinden AG, Rivadeneira F, Zillikens MC, Kiemeney LA, Vermeulen SH, Abecasis GR, Schlessinger D, Schipf S, Stumvoll M, Tönjes A, Spector TD, North KE, Lettre G, McCarthy MI, Berndt SI, Heath AC, Madden PA, Nyholt DR, Montgomery GW, Martin NG, McKnight B, Strachan DP, Hill WG, Snieder H, Ridker PM, Thorsteinsdottir U, Stefansson K, Frayling TM, Hirschhorn JN, Goddard ME, Visscher PM. FTO genotype is associated with phenotypic variability of body mass index. Nature. 2012;490(7419):267-72.

40. Graff M, Scott RA, Justice AE, Young KL, Feitosa MF, Barata L, Winkler TW, Chu AY, Mahajan A, Hadley D, Xue L, Workalemahu T, Heard-Costa NL, den Hoed M, Ahluwalia TS, Qi Q, Ngwa JS, Renström F, Quaye L, Eicher JD, Hayes JE, Cornelis M, Kutalik Z, Lim E, Luan J, Huffman JE, Zhang W, Zhao W, Griffin PJ, Haller T, Ahmad S, Marques-Vidal PM, Bien S, Yengo L, Teumer A, Smith AV, Kumari M, Harder MN, Justesen JM, Kleber ME, Hollensted M, Lohman K, Rivera NV, Whitfield JB, Zhao JH, Stringham HM, Lyytikäinen LP Huppertz C, Willemsen G, Peyrot WJ, Wu Y, Kristiansson K, Demirkan A, Fornage M, Hassinen M, Bielak LF, Cadby G, Tanaka T, Mägi R, van der Most PJ, Jackson AU, Bragg-Gresham JL, Vitart V, Marten J, Navarro P, Bellis C, Pasko D, Johansson Å, Snitker S, Cheng YC, Eriksson J, Lim U, Aadahl M, Adair LS, Amin N, Balkau B, Auvinen J, Beilby J, Bergman RN, Bergmann S, Bertoni AG, Blangero J, Bonnefond A, Bonnycastle LL, Borja JB, Brage S, Busonero F, Buyske S, Campbell H, Chines PS, Collins FS, Corre T, Smith GD, Delgado GE, Dueker N, Dörr M, Ebeling T, Eiriksdottir G, Esko T, Faul JD, Fu M, Færch K, Gieger C, Gläser S, Gong J, Gordon-Larsen P, Grallert H, Grammer TB, Grarup N, van Grootheest G, Harald K, Hastie ND, Havulinna AS, Hernandez D, Hindorff L, Hocking L, Holmens OL, Holzapfel C, Hottenga JJ, Huang J, Huang T, Hui J, Huth C, Hutri-Kähönen N, James AL, Jansson JO, Jhun MA, Juonala M, Kinnunen L, Koistinen HA, Kolcic I, Komulainen P, Kuusisto J, Kvaløy K, Kähönen M, Lakka TA, Launer LJ, Lehne $B$, Lindgren $C M$, Lorentzon M, Luben R, Marre M, Milaneschi $Y$, Monda KL, Montgomery GW, De Moor MHM, Mulas A, Müller-Nurasyid M, Musk AW, Männikkö R, Männistö S, Narisu N, Nauck M, Nettleton JA, Nolte IM, Oldehinkel AJ, Olden M, Ong KK, Padmanabhan S, Paternoster L, Perez J, Perola M, Peters A, Peters U, Peyser PA, Prokopenko I, Puolijoki H, Raitakari OT, Rankinen T, Rasmussen-Torvik LJ, Rawal R, Ridker PM, Rose LM, Rudan I, Sarti C, Sarzynski MA, Savonen K, Scott WR, Sanna S, Shuldiner AR, Sidney S, Silbernagel G, Smith BH, Smith JA, Snieder H, Stančáková A, Sternfeld B, Swift AJ, Tammelin T, Tan ST, Thorand B, Thuillier D, Vandenput L, Vestergaard H, van Vliet-Ostaptchouk JV, Vohl MC, Völker U, Waeber G, Walker M, Wild S, Wong A, Wright AF, Zillikens MC, Zubair N, Haiman CA, Lemarchand L, Gyllensten U, Ohlsson C, Hofman A, Rivadeneira F, Uitterlinden AG, Pérusse L, Wilson JF, Hayward C, Polasek O, Cucca F, Hveem K, Hartman CA, Tönjes A, Bandinelli S, Palmer LJ, Kardia SLR, Rauramaa R, Sørensen TIA, Tuomilehto J, Salomaa V, Penninx BWJH, de Geus EJC, Boomsma DI, Lehtimäki T, Mangino M, Laakso M, Bouchard C,
Martin NG, Kuh D, Liu Y, Linneberg A, März W, Strauch K, Kivimäki M, Harris TB, Gudnason V, Völzke H, Qi L, Järvelin MR, Chambers JC, Kooner JS, Froguel P, Kooperberg C, Vollenweider P, Hallmans G, Hansen T, Pedersen O, Metspalu A, Wareham NJ, Langenberg C, Weir DR, Porteous DJ, Boerwinkle E, Chasman DI; CHARGE Consortium; EPIC-InterAct Consortium; PAGE Consortium, Abecasis GR, Barroso I, McCarthy MI, Frayling TM, O'Connell JR, van Duijn CM, Boehnke M, Heid IM, Mohlke KL, Strachan DP, Fox CS, Liu CT, Hirschhorn JN, Klein RJ, Johnson AD, Borecki IB, Franks PW, North KE, Cupples LA, Loos RJF, Kilpeläinen TO. Genome-wide physical activity interactions in adiposity - A meta-analysis of 200, 452 adults. PLoS Genet. 2017;13(4):e1006528.

41. Cerebrovascular Disease Knowledge Portal, NINDS grant \#1R24NS092983 2018.02.13; http://cerebrovascularportal.org/variantInfo/variantInfo/rs734194.

42. Malik R, Traylor M, Pulit SL, Bevan S, Hopewell JC, Holliday EG, Zhao W, Abrantes P, Amouyel P, Attia JR, Battey TW, Berger K, Boncoraglio GB, Chauhan G, Cheng YC, Chen WM, Clarke R, Cotlarciuc I, Debette S, Falcone GJ, Ferro JM, Gamble DM, llinca A, Kittner SJ, Kourkoulis CE, Lemmens R, Levi CR, Lichtner P, Lindgren A, Liu J, Meschia JF, Mitchell BD, Oliveira SA, Pera J, Reiner AP, Rothwell PM, Sharma P, Slowik A, Sudlow CL, Tatlisumak T, Thijs V, Vicente AM, Woo D, Seshadri S, Saleheen D, Rosand J, Markus HS, Worrall BB, Dichgans M, ISGC analysis group; METASTROKE collaboration; Wellcome Trust case control consortium 2 (WTCCC2); NINDS stroke genetics network (SiGN). Low-frequency and common genetic variation in ischemic stroke: the METASTROKE collaboration. Neurology. 2016;86(13):1217-26.

43. Scott RA, Scott LJ, Mägi R, Marullo L, Gaulton KJ, Kaakinen M, Pervjakova N, Pers $T H$, Johnson AD, Eicher JD, Jackson AU, Ferreira $T$, Lee Y, Ma C, Steinthorsdottir V, Thorleifsson G, Qi L, Van Zuydam NR, Mahajan A, Chen H, Almgren P, Voight BF, Grallert H, Müller-Nurasyid M, Ried JS, Rayner NW, Robertson N, Karssen LC, van Leeuwen EM, Willems SM, Fuchsberger C, Kwan P, Teslovich TM, Chanda P, Li M, Lu Y, Dina C, Thuillier D, Yengo L, Jiang L, Sparso T, Kestler HA, Chheda H, Eisele L, Gustafsson S, Frånberg M, Strawbridge RJ, Benediktsson R, Hreidarsson AB, Kong A, Sigurðsson G, Kerrison ND, Luan J, Liang L, Meitinger $T$, Roden $M$, Thorand B, Esko T, Mihailov E, Fox C, Liu CT, Rybin D, Isomaa B, Lyssenko V, Tuomi T, Couper DJ, Pankow JS, Grarup $N$, Have $C T$, Jørgensen ME, Jørgensen T, Linneberg A, Cornelis MC, van Dam RM, Hunter DJ, Kraft P, Sun Q, Edkins S, Owen KR, JRB P, Wood AR, Zeggini E, Tajes-Fernandes J, Abecasis GR, Bonnycastle LL, Chines PS, Stringham HM, Koistinen HA, Kinnunen L, Sennblad B, Mühleisen TW, Nöthen MM, Pechlivanis S, Baldassarre D, Gertow K, Humphries SE, Tremoli E, Klopp N, Meyer J, Steinbach G, Wennauer R, Eriksson JG, Männistö S, Peltonen L, Tikkanen E, Charpentier G, Eury E, Lobbens S, Gigante B, Leander K, McLeod O, Bottinger EP, Gottesman O, Ruderfer D, Blüher M, Kovacs P, Tonjes A, Maruthur NM, Scapoli C, Erbel R, Jöckel KH, Moebus S, de Faire U, Hamsten A, Stumvoll M, Deloukas P, Donnelly PJ, Frayling TM, Hattersley AT, Ripatti S, Salomaa V, Pedersen NL, Boehm BO, Bergman RN, Collins FS, Mohlke KL, Tuomilehto J, Hansen $T$, Pedersen $O$, Barroso I, Lannfelt L, Ingelsson $E_{\text {, Lind L, }}$ Lindgren CM, Cauchi S, Froguel P, RJF L, Balkau B, Boeing H, Franks PW, Barricarte Gurrea A, Palli D, van der Schouw YT, Altshuler D, Groop LC, Langenberg C, Wareham NJ, Sijbrands E, van Duijn CM, Florez JC, Meigs JB, Boerwinkle E, Gieger C, Strauch K, Metspalu A, Morris AD, CNA P, Hu FB, Thorsteinsdottir U, Stefansson K, Dupuis J, Morris AP, Boehnke M, McCarthy MI, Prokopenko I. DIAbetes genetics replication and metaanalysis (DIAGRAM) consortium. An expanded genome-wide association study of type 2 diabetes in Europeans. Diabetes. 2017;66(11):2888-902.

44. Köttgen A, Pattaro C, Böger CA, Fuchsberger C, Olden M, Glazer NL, Parsa A, Gao X, Yang Q, Smith AV, O'Connell JR, Li M, Schmidt H, Tanaka T, Isaacs A, Ketkar S, Hwang SJ, Johnson AD, Dehghan A, Teumer A, Paré G, Atkinson EJ, Zeller T, Lohman K, Cornelis MC, Probst-Hensch M, Kronenberg F, Tönjes A, Hayward C, Aspelund T, Eiriksdottir G, Launer L, Harris TB, ampersaud E, Mitchell BD, Arking DE, Boerwinkle E, Struchalin M, Cavalieri M, Singleton A,

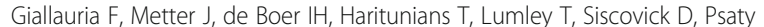
BM, Zillikens MC, Oostra BA, Feitosa M, Province M, de Andrade M, Turner ST, Schillert A, Ziegler A, Wild PS, Schnabel RB, Wilde S, Munzel TF, Leak TS, Illig T, Klopp N, Meisinger C, Wichmann HE, Koenig W, Zgaga L, Zemunik T, Kolcic I, Minelli C, Hu FB, Johansson A, lgl W, Zaboli G, Wild SH, Wright AF, Campbell H, Ellinghaus D, Schreiber S, Aulchenko YS, Felix JF, Rivadeneira F, Uitterlinden AG, Hofman A, Imboden M, Nitsch D, Brandstätter A, Kollerits B, Kedenko L, Mägi R, Stumvoll M, Kovacs P, Boban M, Campbell S, Endlich K, Völzke H, Kroemer HK, Nauck M, Völker U, Polasek O, Vitart V, Badola S, 
Parker AN, Ridker PM, Kardia SL, Blankenberg S, Liu Y, Curhan GC, Franke A, Rochat T, Paulweber B, Prokopenko I, Wang W, Gudnason V, Shuldiner AR, Coresh J, Schmidt R, Ferrucci L, Shlipak MG, van Duijn CM, Borecki I, Krämer BK, Rudan I, Gyllensten U, Wilson JF, Witteman JC, Pramstaller PP, Rettig R, Hastie N, Chasman DI, Kao WH, Heid IM, Fox CS. New loci associated with kidney function and chronic kidney disease. Nat Genet. 2010;42(5):376-84.

Submit your next manuscript to BioMed Central and we will help you at every step:

- We accept pre-submission inquiries

- Our selector tool helps you to find the most relevant journal

- We provide round the clock customer support

- Convenient online submission

- Thorough peer review

- Inclusion in PubMed and all major indexing services

- Maximum visibility for your research

Submit your manuscript at www.biomedcentral.com/submit 